JEL: O11, O31, O32

\title{
FORMATION OF MULTI-PROJECT APPROACH TO REALIZATION OF TARGET DEVELOPMENT PROGRAMS OF HIGH-TECH RESEARCH AND PRODUCTION SYSTEMS AND POWERFUL ENTERPRISES
}

\author{
O.V. Redkin ${ }^{*}$, PhD (Technical Sciences) \\ A.O. Chaikina ${ }^{* *}$, PhD (Economics) \\ National University «Yuri Kondratyuk Poltava Polytechnic»
}

*ORCID 0000-0002-6449-050X

**ORCID 0000-0003-3821-2079

ORedkin O.V., 2020.

(OChaikina A.O., 2020.

Стаття отримана редакиієє 15.09.2020 p.

The article received by the reduction 15.09.2020.

Introduction. The analysis of current progress in the world's leading countries and companies shows that their success is based on the use of innovative high-tech model of continuous development, which is implemented on the basis of advanced standards of strategic, multi-project and project management and the latest advances in science and technology.

In the difficult conditions of the national economy transformation and its transition to market principles of management, the real need nowadays is the search for new effective mechanisms of innovationeconomic and high-tech development of domestic enterprises. Therefore, topic of the study and this article is relevant and has scientific novelty and practical value for the progress of domestic producers.

Review of recent sources and publications. A significant contribution to the research and development of the theory and practice of innovative and economic high-tech progress of the economy and production systems was made by I.O. Halytsia, V.M. Heiets, N.P. Honcharova, N.D. Equiline, N.V. Krasnokutska, O.V. Komelina, A.A. Mazaraki, A.Ye. Nikiforov, O.S. Oliinyk, V.V. Onikiienko, V.O. Onyshchenko, V.P. Seminozhenko, V.D. Stevenson, L.I. Fedulova, R.Ya. Jacobs and others [1-5, 8]. Peculiarities of project management and development programs were studied and developed in the works by S.V. Bushuyeva, V.I. Voropaeva, Yu.N. Zabrodina, N.I. Ilyin, H. Kerner, D. Kendail, D. Cleland, D.K. Pinto, M.L. Razu, V.D. Shapito and others [6-8]. However, given the rapidity and complexity of Ukraine's development processes, available research is insufficient. Therefore, search for new mechanisms for the implementation of innovative and high-tech progress of domestic products and manufacturers is becoming the main task of the modern period of the state development and its economic entities.

Purpose of the article is to highlight the scientific and methodological foundations and practical recommendations for the formation and application of a multi-project approach to the implementation of targeted and comprehensive programs for the development of high-tech research and production systems and powerful enterprises of Ukraine that are able to create, produce and sell level of value added.

Main material and results. Effective implementation of the strategy and programs of high-tech modernization and quality transition of the national economy to an innovative model of sustainable development is most rationally achieved on the basis of multi-project and project management of programtargeted activities in the formation of high-tech research and production systems (HTRPS) in Ukraine. HTRPS allows you to rationally combine and apply the effective elements of the two components of the modern economy: national innovation system (NIS) and high-tech production. Similar systems or their elements can also be organized in the structures of powerful enterprises and companies of Ukraine. As the world experience confirms, such integration of all basic stages and elements of an innovation cycle guarantees not only creation and realization in the world markets of the newest competitive production with a high level of added value, but also provides system decision of other problems of strategic program-target development of the state, its economy, regions, territories and enterprises on the basis of project management. 
From the standpoint of program-target approach and project management, modern innovation and technological progress together with investment activities in target programs and development projects should be combined into the following three processes:

- necessary innovative changes and transformations that set the goals and priorities of relevant development programs and projects. These changes determine the subject part and the results of program and project activities;

- financial and economic activities to attract, use and return investments. Such processes concern the investment sphere (part) of these programs and projects;

- strategic, multi-project and project management of development programs and ongoing projects.

The first two processes, as we know from the theory of project management, form the object of management, and the last - concerns the subject of project management. Together, all three processes are mutually agreed upon during the life cycle of development and implementation of targeted programs for the development of high-tech research and production systems, which will form the basis for the formation of Centers and territories of economic growth and innovative development.

It should be noted that the use of project management together with other mechanisms to ensure innovation and economic progress allows through the formation and implementation of targeted development programs HTRPS to achieve such performance indicators that meet global standards of management and competitiveness.

Therefore, in order to create a subject part of the program-target mechanism and standardized procedures of multi-project management of HTRPS development, the study identified strategic objectives for the main directions and aspects of this process. The list of these tasks, which are given in Table 1, formed on the basis of generalization of the strategic analysis results of a domestic economy condition in comparison with world tendencies of innovative and high-tech development of the advanced post-industrial countries. These tasks specify and complement the set of issues addressed in this study and allow to form a project model of innovation and investment mechanism and algorithm for implementing targeted HTRPS development programs.

Table 1

The main tasks for improving the level of project and multi-project management of innovation and investment development of HTRPS

\begin{tabular}{|c|c|}
\hline $\begin{array}{l}\text { Groups of business } \\
\text { processes that need } \\
\text { improvement }\end{array}$ & $\begin{array}{l}\text { The main tasks to increase the level of strategic planning and project management of } \\
\text { the development of high-tech research and production complex of Ukraine }\end{array}$ \\
\hline 1 & 2 \\
\hline $\begin{array}{l}\text { 1. Market analysis and } \\
\text { consumer needs }\end{array}$ & $\begin{array}{l}\text { Monitor and analyze of the external environment, markets and consumer needs to identify } \\
\text { global trends, identify new innovations, establish specific requirements and conditions for } \\
\text { further development and business activities }\end{array}$ \\
\hline $\begin{array}{l}\text { 2. Strategic analysis of } \\
\text { the state of high-tech } \\
\text { production }\end{array}$ & $\begin{array}{l}\text { Analyze the current state and problems of HTRPS and its products to determine the } \\
\text { potential (strengths and weaknesses) and opportunities for strategic development }\end{array}$ \\
\hline $\begin{array}{l}\text { 3. Formation and / or } \\
\text { improvement of general, } \\
\text { functional and ancillary } \\
\text { strategies }\end{array}$ & $\begin{array}{l}\text { Form (or improve) a systematic view of the mission, overall and innovation and } \\
\text { investment strategy of HTRPS, its individual elements based on external and internal } \\
\text { environmental factors, status, goals and objectives of development to bring HTRPS and its } \\
\text { products to world standards }\end{array}$ \\
\hline $\begin{array}{l}\text { 4. Innovative activity, } \\
\text { processes, projects, } \\
\text { programs }\end{array}$ & $\begin{array}{l}\text { - Develop and implement innovative projects to create new products and appropriate } \\
\text { changes in the structure and processes of HTRPS, as integrated elements of the overall } \\
\text { development program and business activities. } \\
\text { - Develop innovation infrastructure and HTRPS business processes, and create independent } \\
\text { and venture divisions, including science and technology centers (STC), on large and } \\
\text { powerful companies. } \\
\text { - Manage the innovation process according to world standards of strategic and project } \\
\text { management }\end{array}$ \\
\hline $\begin{array}{l}\text { 5. Promotion and sale of } \\
\text { marketable products and } \\
\text { services }\end{array}$ & $\begin{array}{l}\text { Create and develop marketing, developer and other effective systems and areas of activity for } \\
\text { the promotion, marketing and branded service of science-intensive and high-tech innovative } \\
\text { products, including industrial and non-industrial purposes and long-term use }\end{array}$ \\
\hline $\begin{array}{l}\text { 6. Production systems, } \\
\text { processes and their } \\
\text { support }\end{array}$ & $\begin{array}{l}\text { - Carry out innovative progress of technologies, technical-technological base and the } \\
\text { whole production structure of HTRPS according to world standards, including its } \\
\text { functioning, sphere of resource provision, organization and management. } \\
\text { - To develop on a new basis the operational and production management of Ukrainian }\end{array}$ \\
\hline
\end{tabular}




\begin{tabular}{|c|c|}
\hline & $\begin{array}{l}\text { enterprises according to world standards of renewal and continuous improvement of } \\
\text { production systems and business processes of the organization }\end{array}$ \\
\hline $\begin{array}{l}\text { 7. Production and supply } \\
\text { in service-oriented } \\
\text { organizations }\end{array}$ & $\begin{array}{l}\text { Ensure the development of service organizations that complement and develop industrial } \\
\text { enterprises and facilities in the system of national economy and production }\end{array}$ \\
\hline $\begin{array}{l}\text { 8. Settlements with } \\
\text { consumers and branded } \\
\text { service }\end{array}$ & $\begin{array}{l}\text { Develop infrastructure, functions and direct relations with consumers, ensure maximum } \\
\text { implementation of innovation and investment projects and turnkey development programs } \\
\text { with a focus on long-term mutually beneficial cooperation with Ukrainian consumers and } \\
\text { in the field of foreign economic activity }\end{array}$ \\
\hline $\begin{array}{l}\text { 9. Personnel } \\
\text { management (human } \\
\text { resources) and personnel } \\
\text { policy }\end{array}$ & $\begin{array}{l}\text { Constantly improve professional activity and knowledge of staff, human resource } \\
\text { management standards, apply new modern corporate and program-targeted methods of } \\
\text { managing people and their areas of activity: } \\
\text { - ISO } 9000 \text { standards that define the overall system and scope of management; } \\
\text { - advanced standards of project and corporate management of (Project Management Body } \\
\text { Of Knowledge - PMBOK); } \\
\text { - an innovative form of gradual improvement of personnel management based on the Project } \\
\text { Management Maturity Model (PMMM). }\end{array}$ \\
\hline $\begin{array}{l}\text { 10. Information } \\
\text { resources and their } \\
\text { management }\end{array}$ & $\begin{array}{l}\text { Carry out integrated development of information resources of all elements of HTRPS, } \\
\text { projects and programs, strengthening integration and mutually beneficial exchange with } \\
\text { leading innovators and contact audiences of the world }\end{array}$ \\
\hline $\begin{array}{l}\text { 11. Management of } \\
\text { material and financial } \\
\text { resources of high-tech } \\
\text { production }\end{array}$ & $\begin{array}{l}\text { - Improve the quality of material consumption and consumption of energy resources. } \\
\text { Significantly (many times) reduce energy consumption with increasing quality and } \\
\text { competitiveness of products. } \\
\text { - Ensure continuous progress of financial and economic activities of structural elements of } \\
\text { HTRPS, especially in the field of justification, attraction, use and return of investments } \\
\text { involved in development projects and programs. Apply project financing in managing the } \\
\text { development and implementation of business plans, estimates, budget and financial plans, } \\
\text { standards for their implementation }\end{array}$ \\
\hline $\begin{array}{l}\text { 12. Environmental } \\
\text { programs and } \\
\text { management }\end{array}$ & $\begin{array}{l}\text { Implement protection and systematic management in the environmental field, in which } \\
\text { HTRPS needs to interact with the state, regional and local authorities, environmental } \\
\text { organizations and society }\end{array}$ \\
\hline $\begin{array}{l}\text { 13. External } \\
\text { communications } \\
\text { management }\end{array}$ & $\begin{array}{l}\text { Improve the management of external relations, develop effective PR programs, form a } \\
\text { positive image of all elements of HTRPS and its products }\end{array}$ \\
\hline $\begin{array}{l}\text { 14. Management of high- } \\
\text { tech production } \\
\text { development }\end{array}$ & $\begin{array}{l}\text { Systematically and continuously implement a strategic program for development and } \\
\text { ensuring competitiveness of HTRPS and its products according to international standards } \\
\text { of project and corporate governance. Develop the concept of continuous improvement of } \\
\text { the organization, its business processes and areas of activity }\end{array}$ \\
\hline $\begin{array}{l}\text { 15. Development of the } \\
\text { national innovation } \\
\text { system }\end{array}$ & $\begin{array}{l}\text { Creating a competitive domestic research and development sector; increasing the } \\
\text { effectiveness of research and development; development of innovation and investment } \\
\text { mechanism of financial support; creating conditions for technology transfer and } \\
\text { improving the protection of intellectual property rights; introduction of the mechanism of } \\
\text { the state, business, science and production integration; raising the level of innovative } \\
\text { education and culture of society. }\end{array}$ \\
\hline
\end{tabular}

For the successful formation and implementation of targeted HTRPS development programs and the organization of their project management, it is proposed to base the subject and financial and economic parts of program and project activities on a conceptual model of integrated implementation of innovation, production and investment activities throughout the program life cycle.

The proposed conceptual model allows:

- apply the natural flow of the innovation cycle creation and development of new products;

- design and effectively implement any changes in the structure and processes of HTRPS formation, including through the use of various combinations of its elements, external attraction of innovations, transfer of high and critical technologies, acquisition of modern equipment;

- clearly outline the main phases, stages and complexes of work for innovation and investment development program and its projects;

- ensure effective implementation of the program on the basis of world standards of development and project management. 


\section{Organizational and functional model and algorithmof the strategic program of development and activity of HTRPS realization}

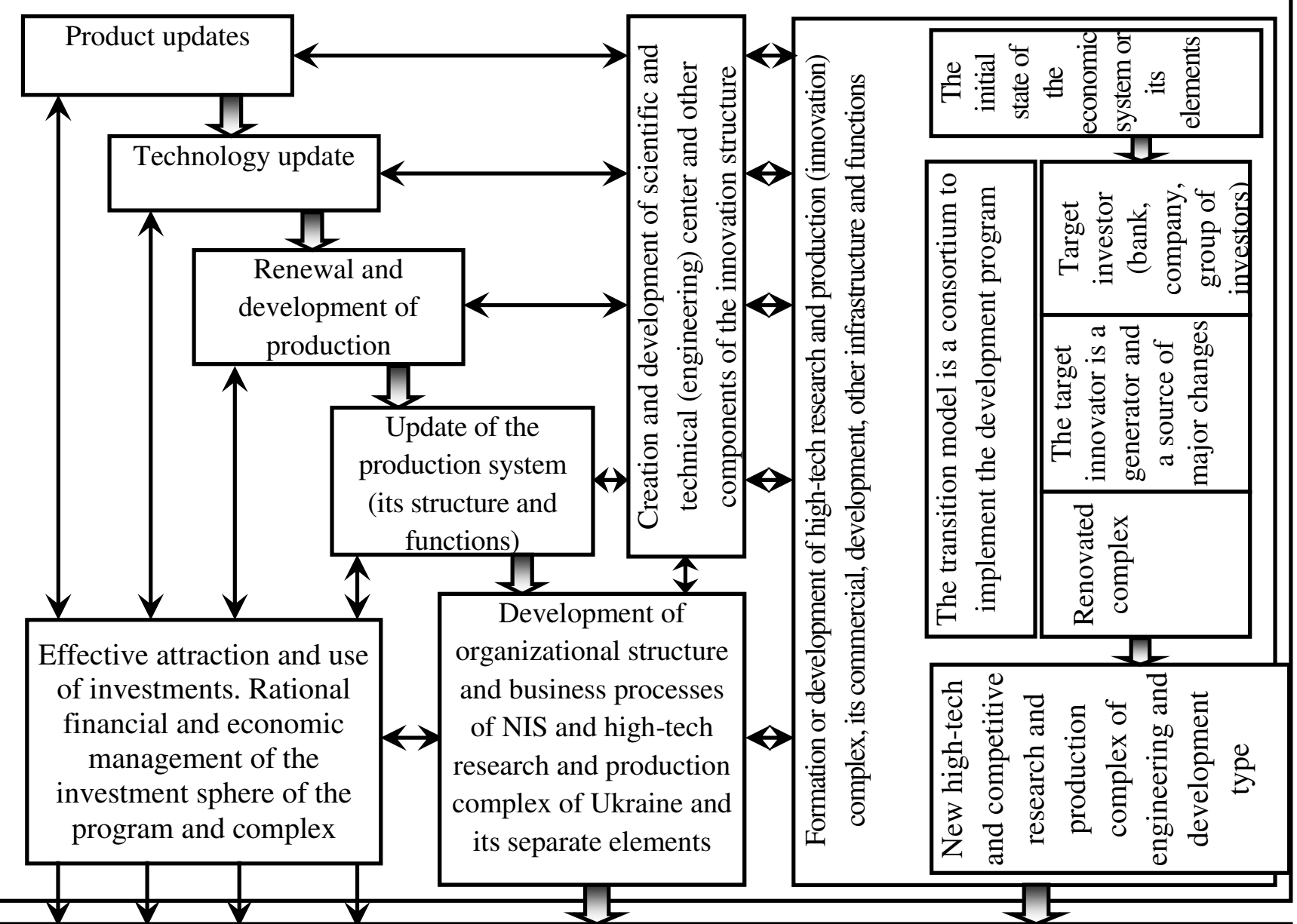

Innovation and investment results of the program: development in Ukraine of an advanced innovative system of creation and high-tech production of science-intensive products, which is constantly developing according to world standards of economic progress and management

Fig. 1. Organizational and functional model of innovation and investment mechanism of formation and activity of HTRPS (author's development)

The best examples of national high-tech research and production complexes (HTRPC) are the modern economies of the United States, Japan, Singapore, Germany and other technologically advanced postindustrial countries, which include various HTRPS of these countries, such as technoparks and technopolises (such as "Silicon Valley" in California, USA; the world's leading innovative companies (such as Boeing, Airbus, General Electric, Sony, Volkswagen), as well as other organizational entities of national and transnational innovation-industrial systems and complexes. At the same time, a new generation of HTRPS has just begun to appear in Ukraine. Therefore, formation of program-oriented high-tech research and production complex of Ukraine should be considered as the main part of the national strategic program of state development, and creation within this complex of a number of high-tech systems that should be considered as priority programs of innovative development of economy, regions and society.

These programs are implemented according to a single algorithm of the project approach to their creation and implementation on the basis of project management standards. This algorithm is developed in the next stages of the study.

To form a project-oriented (program-target) structure and functions of the innovation and investment mechanism to ensure the development of HTRPS and powerful enterprises, in the process of research was carried out its organizational and functional modification, a schematic model of which is shown in Fig. 1. The new model reflects the sequence of organization, operation and development of high-tech research and 
production system (HTRPS). This process involves the implementation of the following areas of development:

a) constant updating of products and technologies $\rightarrow$ improvement and development of high-tech production $\rightarrow$ updating of the production system (its structure, technical-technological base and functions) $\rightarrow$ development of organizational structure and business processes of the research and production complex HTRPS system;

b) development of organizational structures and elements of the national innovation system (NIS), including engineering units (organizations), which ensure the creation of innovations and the implementation of changes within the HTRPS;

c) development of marketing, corporate service and development functions in the innovationproduction and commercial spheres of the national economy;

d) development and implementation of own innovation and investment projects and targeted development programs of HTRPS in Ukraine, creation and sale on the world markets of science-intensive competitive products, solving other tasks of economic progress;

e) attraction and use of investments in rational management of the investment part of the projectprogram mechanism of HTRPS development.

It should be noted that for the implementation of these areas of development and operation of HTRPS in each of the programs it is expedient to provide the decision of the corresponding tasks defined in table. 1.

We can assume that the strategic result of implementation the mechanism of project and multi-project management of innovative development of the national economy will be the presence of a sufficient number of integrated systems of high-tech production and continuous creation of science-intensive products, as well as the use of development and engineering functions and projects in Ukraine. This will allow to develop and manufacture at its own capacity HTRPS (or in cooperation with other complexes) a new generation of competitive products (including sophisticated durables), as well as provide a full range of services and further improve these products in order to maintain its global performance.

When creating models, algorithms and procedures for the implementation of targeted development programs, it is also envisaged to implement a full cycle of turnkey implementation of all innovative projects that will be implemented in the HTRPS system. Therefore, the strategic program of development and further activities of HTRPS should cover the implementation of a number of strategic steps and measures, which are listed in table. 2.

World experience in the use of development and engineering functions and development projects indicates the possibility of obtaining the organizers and implementers of this area of project management the following economic effects compared to traditional forms of innovation and investment progress:

a) reduction of development and implementation of the program duration by $10-15 \%$, including the stage of construction works by $10-25 \%$;

b) reducing the complexity of work on the program by $5-15 \%$;

c) reduction of capital expenditures by $10-22 \%$;

d) reduction of operating costs by $15-25 \%$;

e) reducing the cost of the entire program by $5-15 \%$.

Conducted study and the models formed on its basis allowed to substantiate the structure, content and basic procedures of development and implementation of innovation and investment programs for the development of high-tech systems in Ukraine, as well as to determine organizational and methodological standards of project management throughout its life cycle. Structural and logical scheme of implementation and management of the HTRPS development program, elements of which are shown in Fig. 1, and in general covers and mutually integrates three components and areas of activities of this program:

a) subject area and activity;

b) financial and economic sphere and processes; (HTRPS).

c) project management of the development program of high-tech research and production system

The sequence of implementation and project (multi-project) management of such program is based on the world experience of updating and improving innovative and high-tech production systems and powerful enterprises and modern standards of strategic, multi-project and project management. 
Strategic steps and measures to consider when planning of HTRPS development programs in Ukraine (author's development)

Groups of strategic steps and measures to ensure the effectiveness of the development program
of high-tech research and production system (HTRPS)

1. Innovative component:

a) the use of own developments, projects and programs to create innovative products of world quality and competitiveness;

b) acquisition of start licenses, other property rights for use and development (completion) of production and sale of a new generation competitive science-intensive products and other innovations (including technology transfer) based on the developments of world leaders;

c) acquisition of advanced high-tech production equipment, start licenses and other property rights (use) for its completion and further use in the development of HTRPS based on the creation of a full range of technologies and forms of production, sales, organizational and technological, resource, economic support, maintenance and management of innovative activities and business activities;

d) deep renovation (new construction, expansion, reconstruction and modernization, technical reequipment) of the production, organizational and general structure and infrastructure of the research and production complex;

e) innovations in the field of marketing to ensure the development of HTRPS and the production of new products, its sale (promotion, sale and leasing), branded "lifelong" service, as well as in the development and implementation of other programs for the national economy;

f) creation of an engineering component and functions in the innovation mechanism by harmonious combination of the necessary elements of the innovation infrastructure with the corresponding high-tech production and other elements of HTRPS.

\section{Organizational measures and organizational project:}

a) renewal and development of technical and technological base of high-tech production;

b) improvement and reorganization of the organizational structure, organization of production and labor, as well as the system of production management;

c) automation, cybernetization and comprehensive informatization of various elements and processes of HTRPS, creation of flexible modules and "productions of the future";

d) creation of a powerful innovation infrastructure of HTRPS and its subsystems;

e) organization of an extensive network of trade and service centers and representative offices of HTRPS (and its systems) in Ukraine, in the post-Soviet space, in Europe;

f) development and implementation of modern standards of program-target and project management of innovative development.

3. Formation new standards of professional activity and personnel management systems.

4. Investment component (projects and development programs), which relates to:

a) strategic feasibility study and business planning of the concept and the program itself, its resource and investment support, determining the amount, sources and procedure for financing projects and the program as a whole;

b) development of specific plans and measures of the program, estimates and budget plans of expenditures and revenues, other financial and economic measures;

c) development of standards, organizational and other schemes of financial and economic management during the life cycle of the program;

d) development and use of procedures and tools for comprehensive evaluation of the program effectiveness (and its projects) at all phases and stages of its life cycle.

The main steps in planning and implementing development programs for HTRPS and enterprises that characterize their subject part should be:

1. Development of the program and its projects concept: a) formation or specification of the mission and innovation-investment strategy of HTRPS development; b) formation of an innovative idea and definition of the program and projects purposes; c) conducting strategic marketing research of the program and projects idea to develop a strategy for their implementation; d) identification of a number of possible options for implementing the innovative idea and other measures for the formation of HTRPS; e) formulation of general qualitative and quantitative target parameters of innovative results of the program and its business projects; f) structuring of works on the basis of "tree of purposes" construction and "tree of works"; g) risk 
and uncertainty analysis; h) selection of the basic variant of the decision of the HTRPS development program, its future innovative projects, products and other results of development and activity; i) decisionmaking on the development, planning and implementation of innovation and investment program and its financial (investment) support.

After making this decision, a team of managers of the development and implementation of the program, as well as its individual projects (as a legal, physical, financial, economic and organizational basis for their development and implementation) is created.

2. Planning of works and measures for the development of subject, technological and organizational and economic parts of the program or projects.

3. Development of innovation and investment development program and its projects:

a) organization of design and engineering works to create structural and technological characteristics of the innovative product, general technology of its industrial production; b) organization of experimental production and experimental tests of unique innovative products (technologies) for making additions and changes to the technical project for preparation of working documentation on industrial production of new products; c) design of measures for technological preparation (TP) of unique innovative products; d) organizational design (development of design solutions) for organizational preparation of production (OPP), including construction design; e) development of measures for the organization of new products industrial development, new technologies and production facilities, various structural components of HTRPS, their business processes and functions; f) design and planning of measures to complete the innovation and investment part of the program.

4. Development of a detailed plan for the implementation of the development program, including its individual projects and sets of works.

5. Implementation of innovation and investment program (construction and organization of a new or reorganization and development of existing HTRPS):

a) creation of governing bodies and management system of future or updated HTRPS (processes of its construction, reconstruction and technical re-equipment) with expansion of managers-implementers rights and responsibilities of the program to the powers of business entity to implement program and its projectplanned activities; b) selection of (preliminary) contractors, consultants and suppliers; c) conducting detailed marketing research of the market and consumers (including "trial marketing") to determine the final economic costs and other parameters of production and production; d) formation and nomination of proposals for participation in the program; e) justification of the market price for innovative and other measures of the program; f) contracting for the implementation of software and design solutions; g) construction of a new HTRPS complex or reconstruction and technical re-equipment of its existing structure (site preparation, construction and installation and other works, supply, commissioning and testing of equipment, etc.); h) contracting, ordering and supply of material and technical (production) resources (MTR), development and production of the first constituent industrial batches of new products with simultaneous development of production and other capacities; i) recruitment, training (retraining) of personnel; $j$ ) organization of advertising and monitoring of product promotion; $k$ ) completion of the investment phase of individual projects and development programs: conducting working and state commissions for the commissioning of a new (updated) HTRPS structure and commissioning of the completed complex as a whole.

6. Post-investment phase of project indicators of the program development, organization of current HTRPS activity, transition to the following business projects: a) derivation of HTRPS and its elements on project indicators of innovation-production and commercial activity, beginning of production and sale of science-intensive products; b) organization of current innovation and production processes, logistics and other business processes; c) entering new innovation markets and increasing the level of competitiveness of their own innovations; d) evaluation of the effectiveness of program and project activities and results according to the actually achieved parameters of transformations, innovations and costs; e) transition to the next stages of HTRPS development, development and implementation of new business projects.

Conclusions. Authors convinced that the proposed procedures and tools for the formation and implementation of "turnkey" unique innovation and investment projects and programs for the development of high-tech production at domestic enterprises will ensure their rapid transition to world management standards, accelerate modernization and renewal of products and production systems which will eventually lead to an increase domestic economy competitiveness and increase the welfare of the Ukraine's population. 


\section{REFERENCES:}

1. Heiets V.M., Seminozhenko V.P. Innovative prospects of Ukraine. Kharkiv: Konstanta, 2016. 272p.

2. Nikiforov A.E. Program-targeted management of innovative economic development. Problems of science. 2008. №1. P. 16-24.

3. Innovative paradigm of socio-economic development of Ukraine / Editor V.V. Onikiienko. Kyiv: RVPS NAS of Ukraine, 2006. 480 p.

4. Stevenson W.D. Production management. Minsk: Nauka, 2012. 928 p.

5. Technological modernization of Ukraine / Editor L.I. Fedulova. Kyiv: Institute of Economics and Forecasting, 2008. $472 \mathrm{p}$.

6. Pinto Jeffrey. Project Management. Josses-Bass Publishers, San Francisco. 2013. 464 p.

7. Bushuev S.D. Creative technologies in project and program management. Kyiv: Summit-kniga, 2010.768 p.

8. Redkin O.V., Tolkachov D.M. Strategic and project management of the national economy innovative development, its high-tech research and production systems and enterprises: [monograph]. Poltava: PoltNTU, 2019. 334 p.

УДК 330.005 .342 (477)

JEL: O11, O31, O32

Редкін Олександр Васильович, кандидат технічних наук. Чайкіна Аліна Олександрівна, кандидат економічних наук. Національний університет «Полтавська політехніка імені Юрія Кондратюка». Формування мультипроектного підходу до реалізації цільових програм розвитку високотехнологічних науково-виробничих систем i потужних підприсмств. На основі дослідження стану підприємств України та особливостей зростання передових компаній світу визначено основні завдання щодо підвищення якості проектного й мультипроектного управління модернізацією (удосконаленням) продукції вітчизняних підприємств i розвитком їхніх високотехнологічних систем виробництва. Запропоновано сучасну модель (стандарт) формування та реалізації «під ключ» інноваційно-інвестиційного механізму (проектів і цільових програм) неперервно-циклічного процесу створення наукоємної конкурентоспроможної продукції з високим рівнем доданої вартості та систем іï високотехнологічного виробництва на вітчизняних підприємствах. При цьому враховано світові стандарти господарювання, останні досягнення передової науки і техніки, сучасної теорії стратегічного, мультипроектного, корпоративного та інноваційно-виробничого менеджменту. Визначено порядок, основні процедури та інструменти формування, організації й управління процесами реалізації «під ключ» унікальних інноваційноінвестиційних проектів і цільових програм розвитку високотехнологічних науково-виробничих систем та потужних підприємств в Україні. Розроблено ключові кроки й основні етапи проектнопрограмної діяльності стосовно вдосконалення інноваційно-інвестиційного та виробничогосподарського механізмів підприємства. Запропоновано комплекс практичних заходів щодо ефективного програмно-цільового та проектного управління неперервним інноваційно-економічним $\mathrm{i}$ високотехнологічним розвитком вітчизняної продукції та іï товаровиробників, що охоплюють усі фази, стадії й етапи життєвого циклу відповідних програм і проектів. Упровадження запропонованих механізмів та процедур мультипроектного управління інноваційно-економічним розвитком буде сприяти підвищенню конкурентоспроможності українських товаровиробників, забезпечить більш швидкий їх перехід на світові стандарти господарювання й розвитку, а в кінцевому підсумку - до зростання добробуту населення України.

Ключові слова: мультипроектний i проектний підходи, інноваційні проекти, програми високотехнологічного розвитку.

UDC 330.005.342 (477)

JEL: O11, O31, O32

Redkin O.V., PhD in Technical Sciences. Chaikina A.O., PhD in Economics. National University «Yuri Kondratyuk Poltava Polytechnic». Formation of Multi-Project Approach to Realization of Target Development Programs of High-Tech Research and Production Systems and Powerful Enterprises. Based on the study of the state of Ukrainian enterprises and peculiarities of the world's leading companies growth, the main tasks for improving quality of project and multi-project management of domestic enterprises modernization (improvement) and development of their high-tech production systems were identified. A modern model (standard) of turnkey formation and implementation of innovation and investment mechanism (projects and target programs) of continuous-cyclical process of creating science- 
intensive competitive products with a high level of added value and systems of its high-tech production at domestic enterprises was proposed by authors. In article was considered world management standards, the latest achievements of advanced science and technology, modern theory of strategic, multi-project, corporate and innovation and production management. The basic procedures and tools for the formation, organization and management of turnkey implementation of unique innovation and investment projects and targeted programs for the development of high-tech research and production systems and powerful enterprises in Ukraine were determined. The key steps and main stages of design and program activities to improve investment, innovation and production and economic mechanisms of the enterprise have been developed. A set of practical measures for effective program-targeted and project management of continuous innovationeconomic and high-tech development of domestic products and their producers, covering all phases and stages of the life cycle of relevant programs and projects were proposed. Implementation of the proposed mechanisms and procedures of multi-project management of innovation and economic development will help increase the competitiveness of Ukrainian producers, ensure their faster transition to world standards of management and development, and ultimately - increase the welfare of Ukraine.

Keywords: multi-project and project approach, innovative projects and high-tech development programs. 